\title{
Semiotic Analysis of Sign Systems of Yelets Lace in the Beginning of the XIX Century
}

\section{Svetlana Borisovna Solomentseva}

\author{
Department of Design and Folk Art Culture, Yelets State University n.a. I. A. Bunin, Yelets, Russian Federation \\ Email: ss00001@mail.ru
}

\author{
Doi:10.5901/mjss.2015.v6n4s4p150
}

\begin{abstract}
The purpose of this work is to explore the sign systems of the Yelets lace in the beginning of the XIX century as part of the multi-functional edge semiotic system, to identify and analyse social code contained therein. The relevance of the topic is chosen because currently Yelets lace from developed fishing turns into home crafts, hobbies and gradually disappears from industrial production, retaining only small enterprises. In these circumstances, it is necessary to examine, record, preserve, and promote for future generations cultural traditions reflected in Yelets lace. To achieve this goal have been used philosophicalcultural and cultural-historical approach, cultural and anthropological methodology, and art techniques. The empirical base of the research includes Yelets lace patterns found in the collections of museums and private collections, as well as visual sources available on paper (photographs in books, catalogues and brochures). The work contains the first attempt to classify patterns Yelets multipair bobbin lace late XVIII - early XIX century. Particular attention is paid to the semiotic analysis of three groups of patterns characteristic of multi-pair lace the period under review: geometric, fine, and floral ornaments. The conclusion is that the semiotic status of Yelets lace was high, it was perceived as a sign symbolizing ethnographic, historical, or social and living processes. The results can be used by specialists in the field of folk arts and crafts, museum staff, teachers and students of specialized educational institutions.
\end{abstract}

Keywords: arts and crafts; works of art; design; cultural and anthropological methodology; Yelets lace; semiotic analysis; sign systems; lace; folk costume; decor.

\section{Introduction}

Yelets lace production was formed on the basis of European models in the late XVIII - early XIX century, but gradually changed and transformed, turned into one of the most famous and original types of arts and crafts edge of the specifics of folk art, traditional techniques of composite construction and ornamentation, cultural and historical development processes of society as a whole.

The main purpose of this work is the study of sign systems of Yelets lace of beginning of the XIX century as part of the multi-functional edge semiotic system, the identification and analysis of the social code contained therein. This goal defines the objectives of the study: to analyse the sign systems of Yelets lace as a means of expression of the philosophical and cultural views of its creators; make an attempt to "read" products of Yelets lace makers using decoding coded information in them; consider Yelets lace as an integrated system in which there is a certain social code: worldview and worldview, communication and behaviour. The relevance of the topic chosen because currently Yelets lace is turning from developed industry into home crafts, hobbies and gradually disappears from industrial production, retaining only on small enterprises. In these circumstances, it is necessary to examine, record, preserve, and promote for future generations cultural traditions reflected in Yelets lace. The results can be used by specialists in the field of folk arts and crafts, museum staff, teachers and students of specialized educational institutions.

Thinking of a human being is objectified both in language, and in numerous sign systems. John Locke was the first to use the term "sign" in the scientific revolution. Thoughts about what the signs are symbols of our time, and the idea is an immediate and genuine content of the sign he expressed in his "Essay Concerning Human Understanding" (Locke, 1985).According to the researcher, the signs should be attributed the phenomenon and action items that indicate the information contained in them, and can transmit it. We believe correct to extend the term for Yelets lace as part of decoration and costume houses, part of their semiotic systems.

Semiotic analysis is an important means of studying folk art sign systems that have been passed through both linguistic communication, and using the visual-associative system of symbols, and could be ceremonial, functional, colour, ornamental. Widespread use of sign systems allowed allocating a certain class, ethnic groups, and even culture. However, at the same time, connecting them together to generate a complete picture and understanding of the world 
allows you to organize a learning process and transfer this knowledge to subsequent generations.

Yelets lace is one of the traditional elements of decorative folk costume of southern provinces of Russia. A costume itself is an integrated system that has shaped the content, which is due to its appointment and established traditions. It is organically connected to the utilitarian and artistic property laws into account the volume and rhythm of lines, matching plastics and fabrics and textures all combined organizing role of colour and decoration. The folk costume is identified with the cultural traditions of each of the historical stages of development, is a method of identification, and is one of the most significant ethnic and cultural phenomena.

Since ancient times, the decor of clothing to which Yelets lace refers, had not only functional value, but also was a ritual object, it is a symbol of life processes, so it can be viewed in two ways: as a product and as a sign that characterizes the owner. Studies show that the suit was seen by humanity, as not only a collection of objects that protect the body against adverse conditions, but also as a shaped structure, which reflects the aesthetic, ethnic, religious, and magical beliefs of the people. For example, a new-born baby was wrapped in clothes of parents to ensure health. Very often, christening robe for the baby was father's wedding shirt, which was decorated with special ornaments and embroidered lace on the sleeves and bottom of the product. First baby shirt was also sewed of not a new leaf, but from the well-preserved, bleached clothes of its parents, as it was believed that the power of parental clothes protect and deliver a talisman against the evil eye, damage, witchcraft (Mitryagina, 2005).

Yelets lace, as well as other decorative elements inherent in folk dress is a kind of sign system, allows you to show a person belonging to a certain social environment, and provides image-psychological characteristics of the owner. Status of a costume decorated with Yelets lace is immediately understandable and reflects the lifestyle changes in the material and spiritual world of a human being. In this aspect, the study of semiotics lace is a deep understanding of "social code" and traditions of the people, its faith, aesthetics, ethics, and philosophy. Such an assertion is justified because national suit with all its décor is a manifestation of collective creativity which developed and changed over the centuries and allows you to enable a person in a certain social and cultural environment, in the "space of society" (Lotman, 1992) .Clothing had a strong figurative beginning, where all the decorative elements and symbols, decorating it in harmony and complement each other. Every single element exercised its specific functions and helped to carry out the specific functions of other elements of the costume. However, all of them are aimed at the implementation of a common and basic function - to create a complete system designed for the benefit of a human being.

Lotman defined the entire complex decor folk costume as the object of a kind of "cultural model", a method of modelling the world and turned it into a semiotic system of culture (Lotman, 1992). One theory of the school of sign systems it is an interpretation of symbols and signs as a way to identify the individual, a reflection of inner world.

Lace, embroidery, and weaving patterned in complex Russian folk costumes perform a decorative and magically protective function. It was important to strengthen the defences of clothing, making ownership less vulnerable, so the gate, bottom product, and sleeves decorated with special ornaments - "charms". Their composition reflects the world of a human being, its relation to nature, the relationship with it and was based on the traditional combination of flowers and ornamental species.

\section{Method}

Yelets lace of late XVIII - early XIX century was multi-pair and had complex and multifaceted nature. It was weaved on composite samples, which was a pre-arranged pattern on the thick paper, where they were shown the location of the pins around which the interwoven strands. This type of bobbin lace is different enough frequent weave and fine grid background, background image and run simultaneously. For the manufacture of lace, fifteen centimetres wide with a complex pattern could be used up to three hundred pairs of bobbins. Multi-lace is the most time-consuming and complex kind of lace (Faleeva, 1983).

The compositional structure and the number of patterns within multi-lace motifs are of great variety. N. T. Klimova distinguished the following groups of patterns that are typical of multi-pair lace XIX century: geometric and figurative, which continue to develop the traditions of Russian folk art, especially weaving and embroidery and floral designs, which was formed under the influence of foreign lace, widely distributed in connection with the Western European fashion costume (Klimova, 1993).In our view, this classification can be applied to the bobbin Yelets of late XVIII - early XIX century, but we believe more correct in the third group did not consider the flower, and a more generalized floral ornament.

Note that due to the peculiarities of manufacturing technology of multi-pair bobbin lace graphic pattern is not widely used. However, a few samples of Yelets lace of late XVIII - early XIX century, with this kind of ornament possess identity and special character. The applied method of weaving is reminiscent of European lace tulle on the background at the 
same compositional structure and ornamentation have nothing to do with the foreign samples, and demonstrate the close links to the Russian kinds of arts and crafts: embroidery and weaving.

Yelets lace with fine ornamentation is characteristic straight or rounded contours and traditional motifs, among which are the most common antlered deer and bird peahen. These images are familiar to Russian folk art and endowed with symbolic significance: happiness, goodness, joy, and rebirth of life. They are represented in the traditional interpretation of the plane; their poses are full of vitality, proudly. From these images comes the promise and power of goodwill, there are no signs of threat or intimidation. That is, observed traditions, where the animals and birds were considered reliable protection and support of human rights and members of his family in a happy and prosperous life.

One of the most recognizable patterns of Yelets lace of beginning of the XIX century, it is an image of a deer. According to N. N. Bertyaeva in her work "Russian lace coupling end XVIII - early XX centuries", deer motif often found in ornamental embroidery decision, but it is not widely used in the Russian lace (Bertyaeva, 2010). This can be attributed to the complexity of the coupling technique, especially if multipair lace compared with embroidery. However, the pattern in the shape of a deer in the characteristic of the early Yelets lace that accurately identify the origin of certain samples. For example, the earliest surviving examples dating back to 1801 (Faleeva, 1983), is a thin, multi-lace, made of white linen thread, a composite which is based on a stylized figure of a deer, birds and indispensable element of floral ornament.

The motif of a deer in Yelets lace can be viewed from several sides. In terms of the image of a deer semiotic mainly associated with symbols of fertility of the land, the patronage of the home, family happiness, which bears the imprints of the ancient beliefs of hunters and farmers who have been lost over time, but the idea of benevolence of the image is saved (Maslova, 1978). The constant change of seasons conjured up images of light and dark deer - summer and winter. White golden horn deer symbolizes the summer sky with the sun shining. The image of the deer personified the supreme Slavic gods - Rod (Family) and Rozhanitsy (Parturient), it was believed that the deer is the patron of marriage and family.

On the other hand, the image of a deer in Yelets lace products can be regarded as reproduction of the emblem of the city, which is a symbolic shield in the feather-white background which shows the evergreen fir tree, and under it a proud deer. A study on the history of the Yelets County provides evidence that the appearance of the coat of arms of the city of Yelets was approved in 1781 based on the coat of arms of the Yelets Infantry Regiment. Precise data on the semantic content of the image is not used, but there is a possibility that the deer was associated with courage and valour of soldiers. It is also considering the possibility of association of the city name "Yelets" with spruce and deer as deer in ancient language sounds like "Elen"' (Lyapin 2012).

Fine group of ornaments includes true motive of birds, presented as the previously mentioned sample in 1801, and at the end of above-mirror towels early XIX century (Faleeva, 1983), made in the multi-technique of thin, slightly bleached linen thread. Figures of the welt are composed of complex shapes: deer, birds, and floral ornament elements. These patterns are made in very thick polotnyanka; the contour is decorated with silk. Note that similar to bird on embroidery patterns of Yelets lace products are depicted in profile. Multi-weaving technique typical for Yelets lace is quite limited technical possibilities, so use decorative solutions do not specify bird species, since this is a collective image, and represents a bird-peahen. Stylized figures have the necessary and sufficient detail: drawn wings and tail, legs and eyes are marked. Against the background of the main pattern, which consists of a simple four-sided mesh silhouette of the birds at the same time clearly visible, and if emerges through a delicate background, leaving a very organic impression.

Ornamental bird in the national arts and crafts endowed with special shaped symbols: a bird flying in the sky, the sun warms the earth personified. The image of the bird peahen considered a symbol of prosperity and happiness in family life and is characterized by particularly solemnity and importance (Bertyaeva, 2009).Perhaps that is why this motif is often used in lace products adorning rich dowry of brides.

The geometric ornament is one of the earliest forms of art lace composite construction and it is in the semantics of geometric motifs most fully reflected the sacred representations of our ancestors. The ancient religious and mytho-poetic systems are considered the most common symbols of the cross, circle, square or diamond (Malakhova, 2010). Yelets lace of late XVIII - early XIX century have these elements combined, connected, flow smoothly into one another, forming a distinctive ornamental solutions that attract their expressiveness and conciseness.

One of the oldest preserved examples of Yelets lace of late XVIII - early XIX century is above-mirror towel, which was used for the manufacture of fine linen thread (Faleeva, 1983).Lace is made in multi-pair technique and consists entirely of elements geometric ornament: diamonds, ovals, the edge of the lace is covered by zigzag pattern made in polotnyanka style. Welt and edge are made in Yelets pattern "Slivochki", which is a special kind of twisted way of polotnyanka. "Slivochki" is one of the most characteristic Yelets patterns found in the works of lace throughout the XIX century.

Each of these patterns had its semiotic code that was closely associated with the worship of pagan gods by our 
ancestors and unique style of communicating with them by means of special signs. These characters were to remind the gods of the need to protect people from the dark forces of grief and trouble.

Yelets lace has a widely represented symbol of the circle: it is the already mentioned "Slivochki" and "Pauchki", "Uzenkaya Perevenka" - the land in the form of a thin oval links on a through background, "Pustushka" - a pattern consisting of rings, chains stretched along the edges small "wheels". Often used was oval, which combines rounded shapes: stars, shamrocks and other relief motifs, allowing creating a special black and white impression.

The circle symbolizes unity, the highest perfection, completeness and unity. Sign of the range associated with the daily and annual movement of the sun, which can be conditionally, confirm the widespread, well-established phrase "all year round". Often the circle can be used as a symbol of the sun, giving warmth to humanity and life.

Symmetrical diamond or square is one of the most enduring figures in Yelets ornament lace. To begin with, the main background lace beginning of the XIX century, served as a simple rectangular grid, it is widely used in Yelets lace. The products of this period usually is symmetrical composition solution, small ornamental motifs located in the large diamond-shaped, or is a movement polyline on the background of the patterned or lattice tulle. Traditional patterns were called "Yelets County" and "Shashki" and were close to each other. They were based on an unbroken chain of lozenges with different types of filling. The motif of "Shashki" implies that they are arranged in three rows, and the bottom is firm enough with "Pauchki (spider)" inside (Faleeva, 1983).

The main square of symbolic meanings in the popular mind is wisdom, order, truth, and earth. The combination of square and circle form a stable surface for the "world tree".

Modified square - rhombus defined a sign of fertility and the earth. "Judging by the place in a variety of compositions, it could designate the land, plants and a woman at the same time" (Malakhova, 2010).

The square and the diamond in the minds of the people, and also correlated with the solar cycle, are a symbol of the sun. Picos and pleteshkas, which came out of the party symbolized the rays of that figurative representation of the people was associated with fertility, because the sun was in a close relationship with the old deity Rod (Family).Also, these signs could mean the land, the source of water, fire and life in general.

Quite often one can notice in Yelets lace zigzag compositional structure patterns, especially characterized for decorating edges of products. There were simple teeth made of dense polotnyanka or grid, but the identity of Yelets lace products belongs to complex shaped teeth composed of multiple elements. These geometric ornaments presented the next item of native wildlife - a broken, zigzag line associated with the river, bringing life-giving water to protect them from fire.

Floral ornament of Yelets multipair lace emerged in the first half of the XIX century under the influence of European lace - malines, Valenciennes, and blonde (Davidova, 1892). However, the local masters did not just copy victuals patterns and modify them, they gave a new shape, have made national colours, which enriched the texture of lace. Yelets lace the first half of the XIX century is characterized by subtlety and attention to detail. Distinctive features of this style are light, elegant motifs that reflect the beauty of the landscape, typical of this part of Russia. Traditional Yelets ornament elements are called "melkotravnoe", "bug with colour", "grechishka", and "grechishka with colour".

The main floral ornament was weaved in cloth or polotnyanka and placed on a thin muslin background with different cell structure. The composition of the lace is often quite simple, and the decorative expressiveness achieved contrast openwork and dense background pattern. The compositional base for Yelets lace is ornamental series consisting of flowers, bushes, small branches, and garlands. Wavy, flexible stem was often used, which placed the leaves, flowers, and numerous appendages rounded scrollwork.

These motifs have unique shapes and sectional interpretation, which was based on smooth movement of rounded lines, which gave the whole lace ornamental expressiveness only vaguely resemble real flowers and plants, but not out of touch with the natural prototypes. Yelets lace makers always observed that fine line between the real and decorative way, which is so characteristic of Russian folk art.

Yelets lace floral pattern reflects the overall impression of local lashes from Mother Nature, their ideological approach. The natural properties of the world have identified their inherent symbolism: our ancestors colour means love and fun, shrubs and trees to symbolize contentment, prosperity, and rounded branches on them - a happy life (Maslova, 1978).

\section{Results and Discussion}

Research of the groups of ornaments characteristic of multi-pair lace beginning of XIX century has shown that for a long time semiotic status of the Yelets lace making remained quite high. Often lace was seen as a sign symbolizing ethnographic, historical, or social and living processes. The symbolic nature of Yelets lace creates a collective labour of 
many generations; it had its social and cultural function and allows active involvement of the person in the space of society. Virtually any pattern in addition to the purely decorative function reflects the spiritual world of a human being, their worldview. Yelets lace is a part of syncretic world of our ancestors, which saved social code of mentality, behaviour, and worldview.

\section{References}

Bertyaeva, N. N. (2009). The motives of birds in the Russian ornament lace coupling of the end of XVIII - first half of XIX centuries. Decorative Arts and object space medium. Bulletin of MSAPA, 3, 146-155.

Bertyaeva, N. N. (2010). Russian lace coupling end XVIII - early XX centuries: dissertation for the degree of candidate of art; specialty: 17.00.04. M: MSAPA n.a. S. G. Stroganov.

Davydov S. A. (1892). Russian lace and Russian lace makers. Historical, technical, statistical study. SPb.: Publishing house of A. S. Suvorin.

Klimova, N. T. (1993). People ornamental compositions for art products. Colour bobbin lace. M.: Art.

Locke, John. (1985). Coll. of works: in 3 Vols. Essay Concerning Human Understanding (philosophical heritage). M.: Mysl.

Lotman, Yu. M. (1992). Articles on semiotics and cultural typology. Tallinn: Aleksandra.

Lyapin, D. A. (2012). History of the Yelets County in XVIII - beginning of XX century .Saratov: Novy veter.

Malakhova, T. P. (2010). The motives of geometrical ornament in Russian folk embroidery. Bulletin of the Moscow State Regional University.Series: Psychology, 2, 210-213.

Maslova, G. S. (1978). Ornament Russian folk embroidery as a historical and ethnographic source.M.: Nauka.

Mitryagina, T. A. (2005). Russian folk costume as a value-cultural paradigm: the dissertation for the degree of candidate of philosophical sciences, specialty: 24.00.01. Belgorod: BSU.

Faleeva, V. A. (1983). Russian tatting. L.: Artist of the RSFSR. 